\title{
THE ROLE OF INDONESIAN MEDICAL COUNCIL IN ASSURING THE QUALITY OF MEDICAL EDUCATION
}

\author{
Titi Savitri Prihatiningsih \\ Department of Medical Education, Faculty of Medicine Universitas Gadjah Mada
}

\begin{abstract}
ABSTRAK
Latar belakang: Konsil Kedokteran Indonesia (KKI) didirikan pada bulan Oktober 2005 sebagai mandat dari UU Praktik Kedokteran No.29/2004. Fungsi utama KKI adalah untuk mengawal praktik kedokteran melalui beberapa mekanisme, diantaranya dengan memastikan mutu pendidikan kedokteran dan mengesahkan standar kompetensi dan standar pendidikan kedokteran serta memonitor implementasi standar. UU Pendidikan Kedokteran No.20/2013 diberlakukan. Di dalam UU ini, peran KKI menghilang.

Metode: Studi kualitatif eksplorasi digunakan. Data berupa dokumen yang dianalisis menggunakan analisis konten. Tipologi kerangka regulasi bidang kedokteran diterapkan.

Hasil: Lima kategori berhasil diidentifikasikan, yaitu (i) regulator yang berorientasi pada pendidikan, (ii) rezim regulasi campur, (iii) tata kelola kolaboratif, (iv) regulasi profesi, (v) rezim kredensial campur

Kesimpulan: Dalam tata kelola regulasi, ternyata digunakan regulator yang berorientasi pendidikan; pada penjaminan mutu pendidikan dokter, digunakan rezim regulasi campur, regulasi kolaboratif, dan regulasi profesional. Pada program pendidikan, digunakan regulator yang berorientasi pendidikan. Pada ujian dan kualifikasi digunakan rezim kredensial campur. Ditemukan kontradiksi serius terhadap peran Konsil Kedokteran Indonesia (KKI).
\end{abstract}

Kata kunci: penjaminan mutu, konsil kedokteran, kerangka regulasi kedokteran

\section{ABSTRACT}

Background: Indonesian Medical Council (IMC) was established in October 2005 as mandated by the Medical Practice Law No.29/2004. The main function of IMC is to safeguard the medical practices through several mechanism, one of which is through ensuring the quality of medical education by approving the standards of competences and standards of medical education as well as by monitoring the implementation of those standards. A new Medical Education Law No.20/2013 is enacted. In this Law, the role of IMC in assuring the quality of medical education disappeared.

Method: This is an exploratory qualitative study. Documents are analysed using a content analysis. Typology for medical regulatory framework is applied.

Results: Five categories are identified, namely (1) educationally-oriented regulators, (ii) mix regulatory regimes, (iii) collaborative governance, (iv) professional regulation and (v) mix-credentialing regimes

Conclusion: For governance of medical education, educationally-oriented regulators predominates. In quality assurance for medical education, mix-regulatory, collaborative governance and professional regulation are applied; however there is a contradictory of role between IMC and the Ministry. In funding, mix-regulatory regime and collaborative regime are applied. In education trajectory, educationally-oriented regulator is used and in exam and qualification mix-credentialing regime is applied. Only in quality assurance in medical education, there is a serious contradiction of IMC role.

Keywords: quality assurance, medical council, medical regulatory framework

korespondensi: savitri66yk@gmail.com 


\section{INTRODUCTION}

Medicine has a long tradition of professional regulation - even long before the idea of quality assurance came up in the area of medical education. Professional regulation decides the criteria of professions and criteria for its members, determine the scope of practices, formulate the standards of education, establish ethical and competent practices as well as define the accountability mechanism. ${ }^{1}$ According to Jackson, ${ }^{2}$ a regulatory regime is based on explicit 'rules', i.e. principles, formal requirements, procedures, specifications, standards, charters, codes of practice or best practice guidelines, and frameworks for external quality review. But it is also influenced by implicit "unwritten rules" which are implanted in the accepted norms of behaviour, values, standards, traditions and conditions and conventions. In professional context, effective regulation depends on the mutually reinforcing actions within harder more formalized contexts (written rules, specifications) and within softer, more informal context (i.e. professional norms). Jackson ${ }^{2}$ further explains that there are three types of regulatory regimes. The first is self-regulation where principles, rules, expected conditions which underpin the regulatory framework are entirely determined by the provider of the service or product. The provider is responsible for retaining the integrity of the framework and for ensuring any penalties or actions resulting from non-adherence. The second is external regulation in which the principles, rules, expected conditions underpinning the regulatory framework are laid down by a regulator that is indepenent of the provider of services or products. Adherence to the framework is tested through inspection and the regulator is invested with the powers and authorities to execute penalties if shortcomings are identified. The third is mixed regulation where it contains elements of selfregulation and external regulation. The principles, rules, and expected conditions underpinning the regulatory framework are determined partly by one or more external regulators who are independent of the provider of services and partly by the providers themselves. Responsibility and authority for maintaining the integrity of the regulatory framework are shared between the external regulator and the providers of services/products. The penalties in response to shortcomings are subject to negotiation.

In health professions, the professional associations has been dominants in exercising self-regulation. By applying self-regulation, the health profession can protect the public from practitioners who are unqualified, incompetent and unethical and can promote good practices and prevent poor practices and intervene when practice is unacceptable ${ }^{1 .}$ Jackson also explains that professional bodies usually concern with quality of courses which qualify for entry to a profession, resources to support learning, academic standards via external examinations, and assuring competences of those wishing to practice in the profession. In some countries following the British system, they establish an independent statutory regulatory bodies as a quasi-government body. They are usually mandated by the Government through a Law. This statutory regulatory bodies also concern with the standards of education, quality of courses, as well as competences required to entry the profession

De Vries, et.al ${ }^{3}$ has developed a Typology of Medical Regulatory System as a tool to analyse a medical regulatory system in a country. This typology is used in a comparative study of medical regulatory system in ten countries. Table 1 shows one aspect, namely medical education. 
Table 1. Typology of Medical Regulatory System ${ }^{3}$

\begin{tabular}{|c|c|c|}
\hline Aspect & Dimensions & Details \\
\hline \multirow{5}{*}{$\begin{array}{l}\text { Medical } \\
\text { Education }\end{array}$} & Governance & $\begin{array}{l}\text { - Governance/regulation of medical } \\
\text { education through medically oriented } \\
\text { regulators } \\
\text { Governance/regulation of medical } \\
\text { education through educationally } \\
\text { oriented regulators }\end{array}$ \\
\hline & Quality Assurance & $\begin{array}{l}\text { - Inspection } \\
\text { Extent to which quality standards for } \\
\text { medical education are explicit and public } \\
\text { - Penalties and implications of violations } \\
\text { of minimum quality levels }\end{array}$ \\
\hline & Funding & $\begin{array}{ll}\text { - } & \text { Payers } \\
\text { - } & \text { Annual total cost of medical education } \\
\text { - } & \text { Annual total cost of regulation of medical } \\
& \text { education }\end{array}$ \\
\hline & Education trajectory & $\begin{array}{l}\text { - } \\
\text { - } \\
\text { - } \\
\text { - } \\
\text { Poifferage length to complete each stage } \\
\text { Extent to which doctors specialize } \\
\text { in the health care system } \\
\text { Extent to which medical students are } \\
\text { allowed to train overseas }\end{array}$ \\
\hline & Examination and qualification & 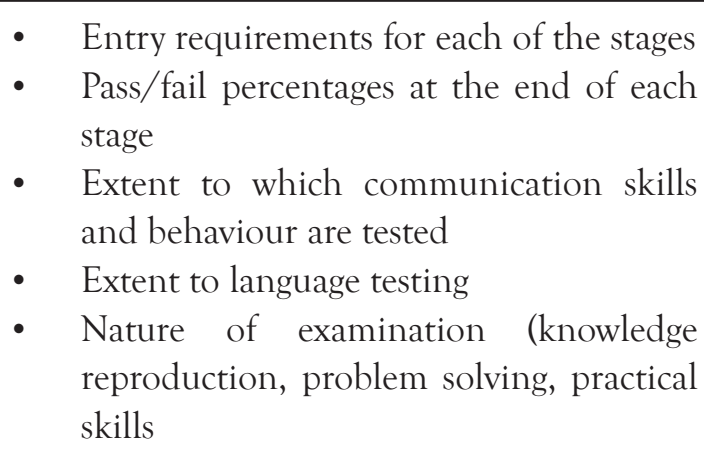 \\
\hline
\end{tabular}

In the ten countries - that is Egypt, Germany, Greece, India, Italy, Nigeria, Pakistan, Poland South Africa and Spain - are examined by de Vries et.al. ${ }^{3}$ All countries examined have structures in place to regulate and quality assure medical education, but the bodies responsible for these functions vary across countries. In India, South Africa and Pakistan the formal regulation of medical education is primarily the remit of medical regulatory body, in others responsibilities are shared between medical council, local authorities, and ministries of health and or ministries of education (Spain, Poland, Germany, Egypt and Greece). Mechanismes of regulation and quality assurance in these countreis included setting of curricula, administering entry exams, issuing degrees, conducting inspections of and issuing accreditations to medical schools and other duties. These appeared to be relatively uncontroversial issues in most of countries being studied. 
Medical education in Indonesia has always become the interests of many stakeholders. Indonesian Medical Association (IMA) which was first established in 1926 used to be the key player in regulating medical education - both for undergraduate, specialist and continuing medical education. To ensure the involvement in medical education regulation, IMA has declared that all associations of specialist, association of general practitioners and association of family medicine are their subordinate organizations. These associations set up colleges which are also controlled by the Indonesian Medical Association. Ministry of Health - is another stakeholder - who also perceives to have the right to also regulate medical education as they are the main user of the medical graduates and as they are in charge of all the hospitals - including teaching hospitals. Ministry of Education - being the regulator in higher education - is in charge to produce ministerial decrees to regulate higher education (including medical education). Ministry of Education is also in charge to grant a permission to open a new medical faculty and a new study programme in medicine and also to close medical schools and programmes which are substandards.

Indonesian Medical Council (IMC) was established in October 2005 as mandated by the Medical Practice Law No.20/2004. The main function of IMC is to safeguard the medical practices through several mechanisms, one of which is through ensuring the quality of medical education by approving the standards of competences and standards of medical education and by monitoring the implementation of those standards. Since 2013, a new Medical Education Law No.20/2013 has been enacted where the role of IMC in medical education has disappeared. Ministry of Education and Culture - later the Ministry of Research, Technology and Higher Education, is the main regulator for all study programmes in higher education institutions, including medical education programmes.

This research is aimed to explore the role of Indonesian Medical Council in regulating medical education. Typology of Medical Regulatory System as developed by de Vries et $a^{3}$ will be used a the framework of analysis.

\section{METHODS}

Qualitative method is applied. Document analysis is used for data collection. Two laws related with medical education regulation are analysed, namely the Law No.29/2004 and Law No.20/2013. Content analysis ${ }^{4}$ is used to analyse the data.

\section{RESULTS AND DISCUSSION}

Tabel 2 shows the results of Content Analysis of the two regulation documents - namely the Law No.29/2004 and Law No.20/2013 - using the Typology of Medical Regulatory System developed by de Vries et.al. ${ }^{3}$

Table 2. Results of Content Analysis

\begin{tabular}{c|c|c|c}
$\begin{array}{c}\text { Dimensions } \\
\text { of Medical } \\
\text { Education } \\
\text { Regulation }\end{array}$ & Law No.29/2004 & \multicolumn{1}{c}{ Law No. 20/2013 } & $\begin{array}{c}\text { Emerging } \\
\text { Categories }\end{array}$ \\
\hline Governance & Not mentioned & $\begin{array}{l}\text { Governance of medical education } \\
\text { programme is by the Faculty } \\
\text { of Medicine and University in } \\
\text { collaboration with teaching hospitals } \\
\text { and professional organization } \\
\text { laid out in the Memorandum of } \\
\text { Understanding (Article 5). }\end{array}$ & $\begin{array}{l}\text { Educationally- } \\
\text { oriented regulators }\end{array}$ \\
\hline & & \\
\hline
\end{tabular}




\begin{tabular}{|c|c|c|c|}
\hline & & $\begin{array}{l}\text { Ministry of Health has the authority } \\
\text { to approve standards of teaching } \\
\text { hospitals and establish the status } \\
\text { of teaching hospitals based on } \\
\text { conformance to standards (Article 14). }\end{array}$ & \\
\hline & & $\begin{array}{l}\text { Contract agreement between Faculty } \\
\text { of Medicine and its teaching hospitals } \\
\text { must include access to facilities and } \\
\text { medical technology for education } \\
\text { and research and is arranged on the } \\
\text { basis of functional and or structural } \\
\text { integration (Article 40-45) }\end{array}$ & \\
\hline \multirow[t]{4}{*}{$\begin{array}{l}\text { Quality } \\
\text { Assurance }\end{array}$} & \multirow{3}{*}{$\begin{array}{l}\text { Indonesian Medical } \\
\text { Council formulates the } \\
\text { education standards of } \\
\text { medical profession together } \\
\text { with Indonesian College } \\
\text { of Medicine, Indonesian } \\
\text { College of Dentistry, } \\
\text { Association of Medical } \\
\text { Schools, Association } \\
\text { of Dental Schools and } \\
\text { Association of Teaching } \\
\text { Hospitals (Article 7). }\end{array}$} & $\begin{array}{l}\text { Supervision is by the Ministry of } \\
\text { Research, Technology and Higher } \\
\text { Education (Article 5) }\end{array}$ & \multirow[t]{4}{*}{$\begin{array}{l}\text { Mix-regulatory } \\
\text { regimes }\end{array}$} \\
\hline & & $\begin{array}{l}\text { Ministry of Research, Technology } \\
\text { and Higher Education decides the } \\
\text { quota of student intake after having a } \\
\text { consultation with Ministry of Health } \\
\text { (Article 9) }\end{array}$ & \\
\hline & & $\begin{array}{l}\text { Faculty of Medicine and Faculty of } \\
\text { Dentistry must assure the quantity, the } \\
\text { quality and sustainability of academic } \\
\text { staffs sufficient to arrange education } \\
\text { programme (Article 17, 21-22) }\end{array}$ & \\
\hline & $\begin{array}{l}\text { Indonesian Medical } \\
\text { Council has the authority } \\
\text { to approve education } \\
\text { standards of medical } \\
\text { profession (Article 7) }\end{array}$ & $\begin{array}{l}\text { Ministry of Research, Technology and } \\
\text { Higher Education establishes national } \\
\text { standards of medical education - } \\
\text { which refers to National Standards of } \\
\text { Higher Educadtion - in collaboration } \\
\text { with Minisry of Health, Association } \\
\text { of Medical Schools, Association } \\
\text { of Dental Schools, Association of } \\
\text { Teaching Hospitals, Professional } \\
\text { Association. }\end{array}$ & \\
\hline
\end{tabular}


Indonesian Medical

Council has the authority

to approves Standards of

Competences (Article 8)
The standards comprise of - at leaststandards of competence, standards of content, process, teaching hospitals, educational vehicles, academic staffs, support staffs, facilities and infrastructures, governance, financing and assessment, standards of research, standards of community services, standards of programme evaluation, standards of contract agreement, standards of monitoring and standards of achievement reports (Article 24

Indonesian Medical

Council has the authority

to measure fitness to

practice and to issue

registrations (Article 8)

Association of Medical
Schools formulate the
Education Standards
for Medical Doctor
in collaboration with
professional organization,
Indonesian Colleague of
Medicine, association of
teaching hospitals, Ministry
of Research, Technology
and Higher Education and
Ministry of Health (Article
26)

Curriculum is developed by each faculty of medicine and faculty of dentistry based on national standards of medical education using principle of diversification (Article 25-26)

\begin{tabular}{l}
\hline $\begin{array}{l}\text { Student selection and recruitment } \\
\text { should confroms with the standards } \\
\text { and comply with the principles of } \\
\text { justrice, affirmative, and transparant } \\
\text { (Article 27-30) }\end{array}$ \\
\hline $\begin{array}{l}\text { Students have rights and must fulfill } \\
\text { their obligation as depicted in the } \\
\text { Ministerial Decree (Article 31) }\end{array}$ \\
\hline $\begin{array}{l}\text { Each Faculty of Medicine must } \\
\text { develop an internal quality assurance } \\
\text { system (Article 47) }\end{array}$ \\
\hline
\end{tabular}




\begin{tabular}{|c|c|c|c|}
\hline & $\begin{array}{l}\text { Medical education } \\
\text { and Dental education } \\
\text { programme must comply } \\
\text { with Educational standards } \\
\text { for medical doctors (Article } \\
\text { 27) }\end{array}$ & $\begin{array}{l}\text { Government facilitates medical } \\
\text { education programmes to achieve the } \\
\text { highest accreditation status through } \\
\text { provision of human resources and } \\
\text { facilities (Article 53). }\end{array}$ & \\
\hline & & $\begin{array}{l}\text { Local governments contribute to } \\
\text { the achievement of quality medical } \\
\text { education and quality teaching } \\
\text { hospitals (Article 55) }\end{array}$ & \\
\hline \multirow[t]{3}{*}{ Funding } & \multirow[t]{3}{*}{ Not mentioned } & $\begin{array}{l}\text { Funding can be obtained from } \\
\text { various resources, including central } \\
\text { government, local government, own } \\
\text { fund from the Faculty, and other } \\
\text { resources. Students must pay the cost } \\
\text { of education in accordance with the } \\
\text { Ministerial Decree (Article 32-34) }\end{array}$ & \multirow[t]{3}{*}{$\begin{array}{l}\text { Mix-regulatory } \\
\text { regimes }\end{array}$} \\
\hline & & $\begin{array}{l}\text { Faculty of Medicine has the obligation } \\
\text { to pay for the cost of education in the } \\
\text { teaching hospitals. }\end{array}$ & \\
\hline & & $\begin{array}{l}\text { The cost of medical education is born } \\
\text { collaboratively between the central } \\
\text { government, local government, } \\
\text { teaching hospitals and the public } \\
\text { (Article 48-52) }\end{array}$ & \\
\hline $\begin{array}{l}\text { Education } \\
\text { trajectory }\end{array}$ & $\begin{array}{l}\text { It is explained in the } \\
\text { Standards of Medical } \\
\text { Profession. }\end{array}$ & $\begin{array}{l}\text { Medical education comprises of } \\
\text { academic mode and professional } \\
\text { mode. Academic mode starts from } \\
\text { bachelor in medicine and bachelor } \\
\text { in dentistry, continued to mastes } \\
\text { and lastly doctorate programme. } \\
\text { Professional mode comprises of } \\
\text { professional phase of undergraduate } \\
\text { medicine and dentistry followed by } \\
\text { internship programme, primary care } \\
\text { physicians, specialist and sub-specialist } \\
\text { pprogramme. }\end{array}$ & $\begin{array}{l}\text { Educationally } \\
\text { oriented regulators }\end{array}$ \\
\hline $\begin{array}{l}\text { Examination } \\
\text { and } \\
\text { qualification }\end{array}$ & $\begin{array}{l}\text { Every medical doctors } \\
\text { must have a sertificate } \\
\text { of competences after } \\
\text { passing the competence } \\
\text { examinations as one of } \\
\text { requirements to get a } \\
\text { registration (Article 29) }\end{array}$ & $\begin{array}{l}\text { Prior to graduation, every medical } \\
\text { student must pass the national } \\
\text { competence-based examination } \\
\text { organized by the Faculty in } \\
\text { collaboration with Association of } \\
\text { Medical Schools and Professional } \\
\text { Organization (Article 36-38) }\end{array}$ & $\begin{array}{l}\text { Mix-credential } \\
\text { regimes }\end{array}$ \\
\hline
\end{tabular}




\author{
Those who pass the national \\ competence-based examination are \\ given professional certificate from the \\ Universities (Article 36) \\ Non-conformance to this Law \\ and the National Standards of \\ Medical Education will be given \\ administration sanctions which \\ includes written reminders up to the \\ revocation (Article 58)
}

According to de Vries et.al ${ }^{3}$ there are five dimensions of regulation under the issue of medical education, namely governance, quality assurance, funding, educational trajectory, and examination and qualification. Articles from the two Laws that have relevant contents with these five dimensions are identified and then categories are inductively discovered as written in the coloumn 'emerging categories' in Table 2 above. namely educationallyoriented regulators, mix-regulatory regime, collaborative regulation, professional regulation, mixcredentialing regime. The following is the description of each category for each dimension.

\section{Category for Governance of Medical Schools is Educationally-oriented Regulators}

The governance of medical schools in Indonesia has always been regulated by the Ministry responsible for education since the Indonesian independence. This is contrary to the situation before Indonesian independence where the governance of the medical schools established by the Dutch Colony was under the authority responsible for health care (Jawatan Kesehatan). ${ }^{5}$

The Ministry of Education and Culture through Directorate General of Higher Education (DGHE) has been the main regulatory body. In 1980s, DGHE established a Consortium of Health Sciences (CHS) with the main remit to give advices to the Director General of Higher Education on the academic development and regulation of health profession education, including the setting up of new programmes or new schools. However, early 2000, $\mathrm{CHS}$ was dismissed. After the reform era, with the enactment of National Education Law No.20/2003,
Indonesian Medical Education faced a new era characterised by 'deregulation of medical schools' and 'medical education reform'. One implication is the rapid increase of new medical schools. As the highest authority in medical education, the Director General of Higher Education (DGHE) needed to control the mushrooming of medical schools to avoid the overproduction of medical doctors and to protect the public interest from unaccountable medical education program.

However, although DGHE was the regulator, DGHE realized the importance of other stakeholders in medical education regulation. A meeting was conducted on 3rd September 2003 led by the DGHE at Building E Ministry of National Education. All relevant stakeholders were invited. An agreement was achieved to establish the Indonesian Medical Education Committee (Komite Pendidikan Kedokteran Indonesia). A Ministerial Decree was issued to give a legal basis for this Committee.

Law No.20/2013 reaffirmed the governance model adopted by the Indonesian Government, namely the educationally-oriented regulators where Ministry responsible for higher education regulates specifically the governance of medical schools. This Law has given a further mandate to the Faculty of Medicine to take the lead in medical education governance which includes deciding contract agreement with the teaching hospitals and other educational vehicles.

According to Prihatiningsih ${ }^{6}$ this situation differs with Bangladesh where governance of medical schools is regulated by the Ministry of Health. In UK, the main actor in governance regulation for medical schools is 
the General Medical Council (GMC) - a statutory body established by the Parliament. De Vries ${ }^{3}$ study also confirmed that in countries where the British System is adopted, the medical councils play a strong role, such as in India, Pakistan, and Egypt.

2. Category for Quality Assurance is Mixregulatory Regime, Collaborative Governance and Professional Regulation

In quality assurance, from the content analysis of the Medical Practice Law No.29/2004 and the Medical Education Law No. 20/2013, three models of regulation are applied - namely mix-regulatory regime, collaborative regulation and professional regulation. As explained by Jackson, ${ }^{2}$ in the mix regulatory regime there is a component of selfregulation and external regulation. Indonesian Medical Council (IMC) which was established in 2005 was mandated by the Medical Practice Law No.29/2004. The members are representatives of Indonesian Medical Association, Indonesian Association of Medical Education Institutions, Indonesian College of Medicine and Ministry of Health. This membership reflects the combination of self-regulation and external regulation.

Angel and Gash ${ }^{7}$ explains that collaborative governance is a governing arrangement where one or more public agencies directly engage nonstate stakeholders in a collective decision making process that is formal, consensus oriented, and deliberative, that aims to make and implement public policy or manage public programme or assets. The composition of Inonesian Medical Council represents the combination of public agencies and non-state stakeholders in several public functions, such as approval of national standards of medical education and standards of competences, ensuring fitness to practices of new medical graduates, and ensuring compliance of standards.

Professional regulation is an external regulation ${ }^{2}$ where professional association concerns with ensuring that the medical education is quality assured in order to make sure that the medical graduates entering the professions meet the competences and qualifications set aside by the Indonesian Medical Association. Through Indonesian College of
Medicine, the professional association who involves in formulating and approving the national standards of medical education.

In Medical Education Law, it is mentioned that each Faculty should have an internal and external quality assurance system. In Medical Practice Law, the acreditation is explained in 'Standards for Education for Medical Doctor' that each institution should have a quality assurance mechanism based on valid standards to ensure supervision and monitoring

The Medical Practice Law No.29/2004 established the Indonesian Medical Council as the key actor in quality assurance of medical education. However, the Medical Education Law No.20/2013 mandated the Ministry responsible for higher education as the main regulator in assuring the quality of medical education. This Law mandated the Ministry to approve national standards of medical education and explain in details what must be included in this national standards. The latter Law also engage professional association, association of medical education institutions, association of teaching hospitals and Ministry of Health in formulating the standards. To implement this mandate, the Ministry has a Directorate of Quality Assurance whose main function is to facilitate the strengthening of internal quality assurance system. Whilst, for the external quality assurance system, an independent accreditation agency for health profession education was officially instituted in February 2015.

As both Laws are currently still active, there are potential conflicts of roles between Indonesian Medical Council and Ministry of Research, Technology and Higher Education (the new Ministry created by the Jokowi Government to deal with higher education affairs - incuding medical education)

\section{Category for Funding is Mix-regulatory Regime} Medical Practice Law No.29/2004 does not explain the issue of funding. On the other hand, the Medical Education Law No.20/2013 describes in detail how the cost of medical education should be met. From the result of content analysis, it is clear that mixed regulatory regime is used. Especially for the medical schools under the legal business-entity body, the sources of fund may vary from the central 
government, local government, own budget, public fund, grants, etc. Under the Medical Education Law, it is explained that various scholarships need to be provided to ensure access and equity for medical education. A proportion of cost should be born by the students.

\section{Category for Education Trajectory is Educatio- nally-oriented Regulators}

For the education trajectory, educationally-oriented regulators - in this case Ministry responsible for higher education - played a significant role. This is in contrast with prior to Indonesian independence where medically-oriented regulators decided the medical education programme..$^{5}$ Indonesian Association of Medical Education Institutions (AIPKI) was established in 2000. Following this establishment, AIPKI recommended to the Director General of Higher Education for a medical education reform. This proposal was accepted and during 2003 . 2008 the Director General of Higher Education reformed the medical education including the formulation of standards for medical education, standards of competences where the design of the medical education programmes was curriculum of medical education to become more competencebased. For this purpose, a substantial investment through a World Bank Project was carried out through a Health Workforce Service (HWS) Project. ${ }^{8}$ The reform was continued from 2009-2014 through Health Profession Education Quality (HPEQ) Project. $^{9}$

\section{Category for Exam and Regulation is Mix- credentialling Regime}

The Medical Practice Law No.29/2004 requires each medical graduate to have a certificate of competence through competence-based examination to get a registration letter that will be used for obtaining a licence for practice from provincial health offices. According to this Law, the competencebased examination are carried out for new medical graduates. Medical Education Law No. 20/2013 explains that every medical student must pass the national competence-based examination organized by the Faculties of Medicine in collaboration with
Association of Medical Schools and Professional Organization. According to this Law, the competencebased examination is organized for medical students at the end of their study. These two mechanisms for credentialling are strongly contradictory and potentially leading to conflicts.

Although from the results of content analysis regarding to exam and qualification, mix-regulatory regime is to be adopted, the role of external stakeholders - in this case is the Indonesian Medical Association - is unclear. The Medical Education Law No.20/2013 strengthens the Ministry of Research, Technology and Higher Education as the leading and main regulator in medical education. The role of IMC as one of the regulators has disappeared. While the Medical Practice Law No.29/2004 is still active and gives a mandate to the IMC as a superregulatory body. Its functions are similar to General Medical Council (GMC) in the UK, namely (i) to keep up-todate registers of qualified doctors, (ii) to foster good medical practice, (iii) to promote high standards of medical education and training, (iv) to deal firmly and fairly with doctors whose fitness to practice is in doubt.

\section{CONCLUSION}

Five themes are discovered using content analysis for the Medical Practice Law No.29/2004 and Medical Education Law No.20/2013, namely (1) educationallyoriented regulators, (ii) mix regulatory regimes, (iii) collaborative governance, (iv) professional regulation, (v) mix-credentialing regimes. The role of IMC in the Medical Practice Law is a superregulatory body especially in quality assurance for medical education, whilst in the Medical Eduation Law the IMC has no roles. These two laws are potentially contradict to each other, more problems to arise, rather than solving the existing problems.

\section{ACKNOWLEDGEMENT}

This paper was accepted as oral presentation' at Association for Medical Education in Europe (AMEE) Conference in Milan, 31st August-4th September 2014. 


\section{REFERENCES}

1. Saif Al-Jabril S, Affara F. Professional self-regulation for nursing and midwifery in Oman: Protecting the public and enhancing the quality of care. Oman Med J. 2016; 243-4.

2. Jackson M. Academic regulation in UK higher education: Part I - the concept of collaborative regulation. Qual Ass in Educ. 1997;5(3):120-35.

3. De Vries H, Sanderson P, Janta B, Rabinovich L, Archantakis F, Ismail S, Klautzer L, Marjanovic S, Patruni B, Puri S, Tiessen J. Technical Report International Comparison of Ten Medical Regulatory Systems: Egypt, Germany, Greece, India, Italy, Nigeria, Pakistan, Poland, South Africa and Spain. Santa Monica: Rand Corporation; 2009.

4. Drisko JW, Maschi T. Content Analysis: Pocket Guides to Social Work Research Methods. New York: Oxford University Press; 2016.

5. Departemen Kesehatan RI. Sejarah Kesehatan Indonesia Jilid 1. Jakarta: Departemen Kesehatan; 1978.

6. Prihatiningsih TS. Quality Assurance in Undergraduate Medical Education: A Multiple Case Study in Thailand,
Bangladesh and Indonesia. PhD Thesis. Dundee: University of Dundee; 2003.

7. Ansel C, Gash, A. Collaborative Governance in Theory and Practice. Journal of Public Administration Research and Theory, 2007;18: 543-71.

8. World Bank. Indonesia - Health Workforce \& Services (php 3). Washington, DC: World Bank Group; 2009. Available from: http://documents. worldbank.org/curated/en/943611475070641129/ Indonesia-Health-Workforce-Services-php-3

9. 0000A8056; 0000A8056. Indonesia - Health Professional Education Quality Project : P113341. Implementation Status Results Report : Sequence 09. Washington, D.C. : World Bank Group; 2014. Available from: http://documents.worldbank.org/ curated/en/805771468284372864/IndonesiaHealth-Professional-Education-Quality-ProjectP113341-Implementation-Status-Results-ReportSequence-09

10. Southgate L, van der Vlueten CPM. A conversation about the role of medical regulators. Medical Education, 2014:48:215-8. 